\title{
АУДИТИВНА КОМПЕТЕНЦІЯ ЯК ОДИН ІЗ ВИДІВ КОМУНІКАТИВНОЇ ДІЯЛЬНОСТІ ПРИ ВИВЧЕННІ АНГЛІЙСЬКОЇ МОВИ
}

\author{
М. І. Бобак, М. Л. Кушик, І. А. Прокоп, О. В. Денефіль, Г. Б. Паласюк, \\ Т. В. Саварин, Л. Я. Вітко, М. О. Сокол \\ ДВНЗ “Тернопільський держсавний медичний університет імені I. Я. Горбачевського”
}

\section{LISTENING COMPREHENSION COMPETENCE AS A MAIN TYPE OF COMMUNICATIVE ACTIVITY WHILE STUDYING THE ENGLISH LANGUAGE}

\author{
M. I. Bobak, M. L. Kushyk, I. A. Prokop, O. V. Denefil, H. B. Palasiuk, T. V. Savaryn, \\ L. Ya. Vitko, M. O. Sokol \\ SHEI "Ternopil State Medical University by I. Ya. Horbachevsky”
}

\begin{abstract}
У статті розглянута проблема адитивної компетенції як одного із видів комунікативної діяльності при вивченні англійської мови. Аналізусться значення навчання аудіювання як спеціальної програми дій з текстом, що сприймається на слух. Зосереджена увага на механізмах аудіювання мовленнсвих одиниць різних рівнів. Окреслюсться мета щодо визначення особливостей формування аудитивної компетенції студентів й оптимальних типів, видів вправ, які спрямовані на формування аудитивних навичок студентів.
\end{abstract}

The article adduces the problem of listening comprehension competence as a main type of communicative activity while studying the English language. The notion of listening comprehension studies as a main program of text action which is perceived by listening, is analyzed. A special attention is paid to the question of listening comprehension mechanisms of vocal units of different levels. The aim of defining peculiarities of forming students' listening comprehension competence and optimal types, types of exercises, that are directed on forming listening comprehension skills of students.

Вступ. У методичному плані навчання аудіювання - це спеціально організована програма дій з текстом, що сприймається на слух. Оскільки це внутрішня діяльність, яка не піддається спостереженню, то необхідно поступово навчати окремих дій, які є їі складовими компонентами. Ці дії є об'єктом цілеспрямованого формування i розглядаються як проміжні цілі навчання аудіювання. Досягнення проміжних цілей проходить поетапно. На кожному етапі формуються відповідні механізми аудіювання мовленнєвих одиниць різних рівнів: 1) словоформи, вільного словосполучення, фрази; 2) понадфразової єдності; 3) цілого тексту. За допомогою цих дій розвивається механізм прогнозування, який відіграє дуже важливу роль у сприйманні мовлення на слух.

Основна частина. Тема цього дослідження $є$ однією з найактуальніших тем у сучасній методиці навчання іноземної мови, оскільки без аудіювання неможливе мовне спілкування. І недооцінка аудіювання може вкрай негативно позначитися на мовній підготовці студентів. Вивчення цього виду мовленнєвої діяльності в методиці недостатньо глибоке, а термін “аудіювання” використовується в методичній літературі порівняно недавно. Він протиставляється терміну “слухання". Якщо “слухання” означає акустичне сприйняття звуків, то поняття “аудіювання” включає процес сприйняття i розуміння звукової мови. Також відомо, що “аудіювання” дуже важкий вид мовної діяльності. А те, що сучасні випускники шкіл практично не володіють даним умінням, зовсім не таємниця.

Взагалі, аудіювання як дія, що входить до складу усної комунікативної діяльності, використовується в спілкуванні, яке підпорядковується виробничим, суспільним чи особистим потребам.

І звичайно ж, аудіювання може бути окремим видом комунікативної діяльності зі своїм мотивом, що відображає потреби людини або характер їі діяльності. У такій ролі воно виступає, наприклад, під час перегляду фільму, телепередачі, прослуховування радіопередачі і т. д.

Предметом дослідження є визначення особливостей формування іншомовної аудитивної компетенції студентів. 
Мета даного дослідження полягає у визначенні особливостей формування аудитивної компетенції студентів і у визначенні оптимальних типів та видів вправ, спрямованих на формування аудитивних навичок студентів.

Завдання дослідження:

1. Розглянути теоретичні основи навчання аудіювання.

2. Визначитиосновні труднощі розуміння мови на слух.

3. Визначити оптимальні типи і види вправ, які спрямовані на формування аудитивних навичок студентів.

Термін “аудіювання” був запроваджений в літературі американським психологом Брауном. Аудіювання - це розуміння сприйнятого на слух усного мовлення. 3 точки зору психофізіології аудіювання трактується як перцептивна розумова мнемічна діяльність. Аудіювання повинно займати важливе місце вже на початковому етапі навчання іноземної мови. Оволодіння аудіюванням дає можливість реалізувати виховні, освітні і розвиваючі цілі. Воно дозволяє навчати студентів уважно прислухатися до звукової мови, формувати вміння передбачати значення змісту вислову $\mathrm{i}$, таким чином, виховувати культуру слухання не тільки на іноземній, але і на рідній мові. Виховне значення формування уміння розуміти мову на слух полягає в тому, що воно позитивно впливає на розвиток пам'яті людини, i, перш за все, на розвиток слухової пам' яті, яка є важливою не тільки для вивчення іноземної мови, але і будь-якого іншого предмета [3].

За допомогою аудіювання досягається і освітня мета. Студенти мають можливість розуміти висловлювання, якими б елементарними вони не були, на мові іншого народу, в даному випадку на англійській мові, одній $з$ найпоширеніших мов світу. Аудіювання служить і важливим засобом вивчення іноземної мови. Воно дає можливість опановувати звукову систему мови, що вивчається, іiі фонетичний складі інтонацію: ритм, наголос, мелодику. Наприклад, на початковому етапі, викладач вчить студентів розрізняти звуки ізольовано і в поєднаннях, чути різницю, довготу i стислість, кількісні і якісні характеристики звуків.

Через аудіювання відбувається засвоєння лексичного складу мови і іiї граматичної структури. Так, наприклад, студенти через аудіювання опановують слова polycardia, schema, pressure, anxiety, state of blood і т. д. Перевірка розуміння відбувається тоді, коли студент дає коротку відповідь на запитання. Таким чином здійснюється і навчання розуміння структур різного типу: стверджувальних, питальних, заперечних. У цей же самий час аудіювання полегшує оволодіння говорінням, читанням і письмом [2].
Етап навчання аудіювання на рівні цілого тексту передбачає дії, за допомогою яких досягається:

- розуміння зв'язного (монологічного) мовлення, побудованого на повністю знайомому матеріалі, шляхом членування тексту на смислові частини або виділення інформаційних точок; реакція на почуте невербальна (дії, символи тощо);

- розуміння повідомлення з незнайомим мовним матеріалом; реакція на почуте - невербальна або вербальна як у процесі слухання, так і після нього;

- розуміння діалогічного тексту, побудованого на знайомому матеріалі, із завданням на виявлення кількості учасників бесіди, їх характеристик; реакція вербальна або у вигляді відповіді на запитання, тесту множинного вибору і т. п.;

- розуміння зв'язного тексту, що містить деякі незнайомі елементи: слова, словосполучення, про значення яких можна здогадатися на підставі співзвучності 3 рідною мовою (опора на здогадку, мовний досвід); розуміння можна перевірити за допомогою тесту множинного вибору, відповідей на запитання і т. п.;

- розуміння зв'язного тексту з деякими незнайомими елементами, але здогадка про їх значення здійснюється за формальними ознаками з опорою на знання та асоціативні зв'язки в іноземній мові;

- розуміння зв' язного тексту з наявними незнайомими елементами; здогадка про їх значення здійснюється за контекстом, з опорою на смислові зв'язки;

- розуміння зв'язного тексту, побудованого переважно на незнайомому матеріалі, але з виділенням спеціальних перешкод з метою подолання їх шляхом перепитувань, прохання уточнити сказане і т. д.[2].

Визначальними рисами аудіювання як виду мовленнєвої діяльності в методиці навчання іноземних мов вважаються такі:

1. За характером мовленнєвого спілкування аудіювання, як і говоріння, відноситься до видів мовленнєвої діяльності, що реалізують усне безпосереднє спілкування (хоча інформація може передаватись і технічними засобами), i через це протистоїть читанню і писемному мовленню, які реалізують спілкування, опосередковане письмом.

2. За своєю роллю у процесі спілкування аудіювання є реактивним видом мовленнєвої діяльності, так само, як і читання.

3. За спрямованістю на прийом і видачу мовленнєвої інформації аудіювання, як і читання, $є$ рецептивним видом МД.

4. Форма перебігу процесу аудіювання - внутрішня, невиражена, на відміну від говоріння і письма, які актуалізуються у зовнішньому плані. Основою внут- 
рішнього механізму аудіювання $є$ такі психічні процеси, як сприйняття на слух, увага, розпізнавання та зіставлення мовних засобів, їх ідентифікація, осмислення, антиципація, групування, узагальнення, утримання в пам'яті, умовивід, тобто відтворення чужої думки та адекватна на неї реакція. Отже, предметом аудіювання є чужа думка, яка закодована в аудіотексті і яку належить розпізнати.

5. Продуктом аудіювання є умовивід, результатом - розуміння сприйнятого смислового змісту і власна мовленнєва та немовленнєва поведінка [3].

Виявлено, що структура аудіювання, як і говоріння, складається $з$ трьох частин: спонукально-мотиваційної, аналітико-синтетичної і виконавчої. Проте роль і співвідношення цих частин специфічні. Так, мотиваційно-цільовий аспект аудіювання не тільки визначається потребами слухача, але й опосередко-

\section{Лiтература}

1. Бухбиндер В. А. Основы методики преподавания иностранных языков / В. А. Бухбиндер, В. Т. Штраус. - Киев : Вища школа, 1986. -335 с.

2. Пассов Е. И. Программа-концепция коммуникативного иноязычного образования : Концепция ... 5-11 классы / Е. И. Пассов. - Москва : Просвещение, 2000. - С. 77 78 .
}

вується діяльністю говоріння іншого учасника спілкування. Метою аудіювання є осмислення почутого мовленнєвого повідомлення.

Сприйняття мовлення на слух супроводжується подоланням труднощів, викликаних переважно трьома факторами: індивідуально-психологічними особливостями слухача, умовами сприймання та мовними особливостями мовленнєвого повідомлення.

Висновок. Отож, володіння аудіюванням як видом мовленнєвої діяльності повинно забезпечувати успішний процес комунікації, розвивати вміння студентів говорити іноземною мовою і розуміти іiі, а оскільки цей процес складний і важкий, то потрібно приділяти йому більше уваги. Дуже важливо підвищити і мотивацію студентів до розуміння іноземної мови на слух. Адже, на сьогодні, $\epsilon$ всі умови для вдосконалення процесу навчання аудіювання.

3. Ніколаєва С. Ю. Практикум з методики викладання іноземних мов у вищих навчальних закладах : посібник для студентів/ С. Ю. Ніколаєва, Г. С. Бадаянц. -К. : Ленвіт, 2001. -298 c.

4. Елухина Н. В. Обучение аудированию в русле коммуникативно ориентированной методики / Н. В. Елухина. Москва : ИЯШ, 1989. - №2.- С. 28-36. 